\title{
PENINGKATAN PRESTASI BELAJAR BAHASA INDONESIA MELALUI MEDIA GAMBAR PADA TEMA BUDI PEKERTI MATERI BERCERITA SISWA KELAS II SDN KEDONDONG 2 GAJAH DEMAK
}

\author{
Saidun $\bowtie$
}

Guru SDN 2 Kedondong Gajah Demak

Jawa Tengah, Indonesia

\section{Info Artikel \\ Abstract}

Sejarah Artikel:

Diterima Januari 2017

Disetujui April 2017

Dipublikasikan Juni 2107

Keywords:

Prestasi Belajar Bahasa

Indonesia, Media Gambar,

Tema Budi Pekerti
The purpose of this class action research is to find out how far the improvement of student achievement in SDN Kedondong 2 through the use of media images. In this action research is done in 3 cycles, from the result of action done proven to improve student achievement by reaching ideal standard. From $59.57 \%$ in Cycle I, it can increase to $64.35 \%$ in cycle II, and the third cycle increased to $77.83 \%$. The results of this action study indicate that the use of media images in Indonesian language lessons can improve student achievement on the material tells the story with completeness reached $91 \%$. The students' response to the Indonesian language learning on the theme of the material mind tells the story by using very positive image media. It can be concluded that the improvement of Indonesian language learning achievement through effective drawing media applied to students in SDN Kedondong 2 Gajah Demak.

\section{Abstrak}

Tujuan penelitian tindakan kelas ini yakni untuk mengetahui peningkatan prestasi belajar siswa di SDN Kedondong 2 melalui penggunaan media gambar. Dalam penelitian tindakan ini dilakukan dalam 3 siklus. Berdasarkan hasil tindakan yang dilakukan terbukti dapat meningkatkan prestasi belajar siswa dengan mencapai standar ideal. Dari 59,57 \% pada Siklus 1, dapat meningkat menjadi 64,35 \% pada siklus II, dan siklus ke III meningkat menjadi 77,83\%. Hasil penelitian tindakan ini menunjukkan bahwa penggunaan media gambar dalam pelajaran bahasa Indonesia dapat meingkatkan prestasi belajar siswa pada materi bercerita dengan ketuntasan mencapai $91 \%$. Tanggapan siswa terhadap pembelajaran Bahasa Indonesia pada tema budi pekerti materi bercerita dengan menggunakan media gambar sangat positif. Dapat disimpulkan bahwa peningkatan prestasi belajar Bahasa Indonesia melalui media gambar efektif diterapkan pada siswa di SDN Kedondong 2 Gajah Demak.

(C) 2017 Universitas Muria Kudus

\footnotetext{
$\triangle$ Alamat korespondensi:

Program Studi Pendidikan Guru Sekolah Dasar

Fakultas Keguruan dan Ilmu Pendidikan Universitas Muria Kudus

Kampus UMK Gondangmanis, Bae Kudus Gd. L. 1t I PO. BOX 53

Kudus

Tlp (0291) 438229 ex.147 Fax. (0291) 437198

E-mail: saidun@gmail.com
}

p-ISSN 2087-9385 e-ISSN 2528-696X 


\section{PENDAHULUAN}

Memasuki era globalisasi yang meliputi hampir segala aspek kehidupan manusia, maka sebagai bangsa yang besar, bangsa Indonesia harus meningkatkan kualitas sumber daya manusia yang dimilikinya, yakni sumber daya yang berkemampuan lanjut. Peran ilmu dan teknologi yang sangat besar, sehingga jalur utama untuk meningkatkan sumber daya manusia melalui pendidikan (Nur, 1996).

Pendidikan merupakan usaha sadar untuk menyiapkan siswa melalui kegiatan bimbingan, pengajaran, dan latihan bagi peranannya di masa yang akan datang.

Menurut Nur (1996) peningkatan sumber daya manusia sebagai individu, dalam rangka pengembangan IPTEK dan pemecahan masalah pembangunan meliputi dimensi sebagai berikut.

(1) Intelektual,antara lain daya kreasi, mampu melakukan penelitian yang mendasar dan mendalam serta, cerdas, kritis dan daya nalar yang tinggi.

(2) Moral emosional, yakni etos kerja yang kuat, nilai sikap, kemampuan untuk mencapai prestasi yang setinggi tingginya, budi pekerti luhur,motivasi mengembangkan diri, berorientasi pada prestasi keunggulan dan percaya diri.

(3) Sosial, kerjasama, kekeluargaan, kebersamaan, matang, berkesinambungan, bertanggung jawab, disiplin.

(4) Spiritual, keimanan dan ketaqwaan.

(5) Fisik, kebugaran dan ketahanan.

(6) Peningkatan hasil belajar siswa di sekolah dasar diperlukan berbagai strategi dan inovasi oleh guru dalam proses belajar mengajarnya. Inovasi dalam strategi pembelajaran diperlukan termasuk dalam mata pelajaran bahasa indonesia agar diperoleh ketuntasan belajar siswa yang maksimal.

Kondisi di sekolah dasar di Sumbawa ditemukan bahwa hasil belajar siswa sangat rendah. Sesuai dengan tuntutan kurikulum tingkat satuan pendidikan (KTSP) dalam buku petunjuk teknis menyatakan bahwa siswa dianggap berhasil secara klasikal bila daya serapnya mencapai $85 \%$ dan mendapatkan nilai di atas 6,50.

Setelah dilakukan diskusi dengan beberapa teman guru pada tingkat Gugus melalui KKG (Kelompok Kerja Guru), maka rendahnya hasil belajar siswa terutama pada mata pelajaran bahasa indonesia disebabkan oleh dua faktor yakni (1) dari pihak guru seperti peranan guru masih dominan dalam belajar mengajar. Kondisi ini berdampak negatif terhadap perkembangan jiwa siswa dalam belajar. Konsekuensinya akan melahirkan pembelajaran yang tegang, kaku, verbal, otoriter, dan individualis; (2) dari pihak siswa seperti minat belajar rendah, kurangnya perhatian siswa terhadap materi pelajaran. Hal ini berdampak hilangnya motivasi dan tidak antusiasnya siswa dalam belajar, akibat guru mendominasi dalam pembelajaran.

Upaya peningkatan hasil belajar siswa di sekolah dasar penulis menganggap perlu pemakaian media yang kontekstual. Dengan penggunaan media maka emosi para siswa akan digiring memasuki materi pembelajaran, sehingga mereka akan lebih mudah mengingat kembali materi tersebut.

Khusus untuk pelajaran bahasa indonesia di sekolah dasar yaitu dengan menggunakan media pengalaman langsung melalui media gambar. Berdasarkan pengetahuan dan pengalaman peneliti bahwa pelaksanaan proses belajar mengajar tanpa menggunakan media, siswa kurang termotivasi dalam belajarnya. Apalagi pada jam - jam akhir pelajaran.

Upaya yang dapat dilakukan untuk mengatasi permasalahan di atas adalah melakukan kegiatan mengajar dengan merangsang motivasi siswa melalui pengalaman langsung. Menurut Shel et al (1995) pengalaman belajar menunjukkan tingkat daya serap $90 \%$ dari yang dikatakan dan dilakukan dalam proses belajar mengajar. Sedangkan yang dibaca $10 \%$, didengarkan $20 \%$, dilihat dan didengar $50 \%$ dan $70 \%$ dari yang dikatakan. Sejalan dengan pandangan Mel Seilberman (2002) dalam bukunya "active learning" yang pada prinsipnya : apa yang saya dengar saya lupa, apa yang saya lihat ingat sedikit, apa yang saya dengar, lihat dan diskusikan dan kerjakan saya mulai mengerti dan apa yang saya dengar, lihat, diskusikan dan kerjakan saya dapat pengetahuan dan keterampilan serta apa yang saya ajarkan saya kuasai.

Meningkatkan hasil belajar siswa sekolah dasar (SD) peneliti menganggap perlu menggunakan media dan strategi pembelajaran dan kontekstual. Dengan pemakaian media dan strategi yang kontekstual maka, emosi siswa akan digiring memasuki materi pembelajaran, sehingga mereka akan lebih mudah mengingat kembali materi tersebut. Melalui penggunaan media maka proses belajar mengajar akan terhindar dari pembelajaran yang bersifat verbal dan sekaligus akan dapat meningkatkan motivasi belajar siswa.

Berdasarkan identifikasi permasalahan di atas dapat dirumuskan permaslahan (1) bagaimana penggunaan media gambar dalam pembelajaran bahasa indonesia untuk 
meningkatkan prestasi belajar siswa kelas II di SDN Kedondong 2 Kecamatan Gajah Kabupaten Demak Tahun Pelajaan 2016-2017; dan (2) bagaimana efektivitas penggunaan media gambar dalam pembelajaran bahasa indonesia dalam meningkatkan prestasi belajar siswa kelas II di SDN Kedondong 2 Tahun Pelajaan 2016-2017.

\section{METODE PENELITIAN}

Subjek dalam penelitian ini, Siswa SDN Kedondong 2 Gajah Demak Kelas II tahun pelajaran 2016/2017. Jenis penelitian ini merupakan penelitian tindakan melalui media gambar sebagai upaya peningkatan hasil belajar bahasa Indonesia. Jumlah siswa terdiri atas 23 orang ( laki-laki $=14$ orang dan perempuan $=$ 9 orang ).

Penelitian dilaksanakan pada semester genap tahun 2016/2017, dimulai pada Januari sampai Februari 2017. Dalam pelaksanaan tindakan, rancangan dilakukan dalam 3 siklus yang meliputi (a) perencanaan, (b) tindakan, (c) pengamatan, dan (d) refleksi. Berikut bagan alur penelitian tindakan kelas.

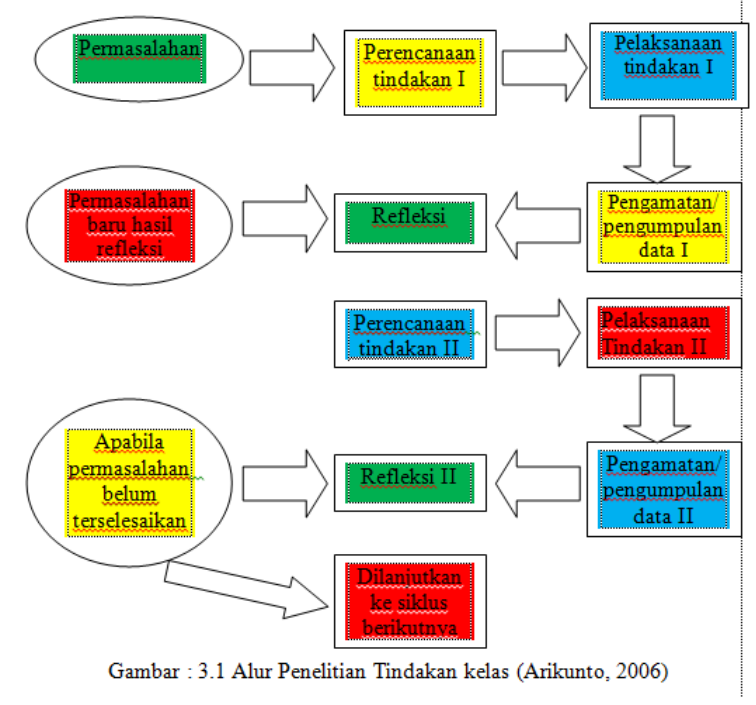

\section{Perencanaan}

Tahapan ini berupa rancangan tindakan yang menjelaskan tentang apa, mengapa, kapan, di mana, oleh siapa, dan bagaimana tindakan tersebut dilakukan. Pada penelitian ini, peneliti dan guru adalah orang yang berbeda, dalam tahap menyusun rancangan harus ada kesepakatan antara keduanya. Rancangan harus dilakukan bersama antara guru yang akan melakukan tindakan dengan peneliti yang akan mengamati proses jalannya tindakan. Hal tersebut untuk mengurangi unsur subjektivitas pengamat serta mutu kecermatan pengamatan yang dilakukan.

\section{Tindakan}

Pada tahap ini, rancangan tindakan tersebut tentu saja sebelumnya telah dilatih kepada si pelaksana tindakan (guru) untuk dapat diterapkan di dalam kelas sesuai dengan skenarionya. Skenario dari tindakan harus dilaksanakan dengan baik dan tampak wajar.

3. Pengamatan atau observasi

Tahap ini sebenarnya berjalan bersamaan dengan saat pelaksanaan. Pengamatan dilakukan pada waktu tindakan sedang berjalan. Oleh sebab itu, keduanya berlangsung dalam waktu yang sama. Pada tahap ini peneliti (atau guru apabila ia bertindak sebagai peneliti) melakukan pengamatan dan mencatat semua hal yang diperlukan dan terjadi selama pelaksanaan tindakan berlangsung. Pengumpulan data ini dilakukan dengan menggunakan format observasi / penilaian yang telah tersusun, termasuk juga pengmatan secara cermat pelaksanaan skenario tindakan dari waktu ke waktu serta dampaknya terhadap proses dan hasil belajar siswa.

\section{Refleksi}

Tahapan ini dimaksudkan untuk mengkaji secara menyeluruh tindakan yang telah dilakukan, berdasarkan data yang telah terkumpul, kemudian dilakukan evaluasi guna menyempurnakan tindakan berikutnya.

Refleksi dalam PTK mencakup analisis, sintesis, dan penilaian terhadap hasil pengamatan atas tindakan yang dilakukan. Jika terdapat masalah dari proses refleksi maka dilakukan proses pengkajian ulang melalui siklus berikutnya yang meliputi perencanaan ulang, tindakan ulang, dan pengamatan ulang shingga permasalahan dapat teratasi (Hopkins, 1993).

Data yang diperoleh berupa data kuantitatif dan kualitatif. Teknik pengumpulan data yang digunakan yaitu observasi dan tes. Analisis data kuantitatif digunakan untuk menghitung besarnya peningkatan prestasi belajar siswa melalui pembelajaran dengan menggunakan media gambar dengan persentase (\%), sedangkan analisis data kualitatif dilakukan dengan cara mereduksi data, menyajikan data secara deskriptif dan penarikan simpulan.

Penelitian ini dikatan berhasil jikan telah memenuhi kriteria terjadi peningkatan prestasi belajar siswa dalam pembelajaran di kelas II semester II SDN Kedondong 2 mencapai $85 \%$ (kelas yang diteliti) telah mencapai ketuntasan dengan nilai rata rata 75 . Berarti telah memenuhi harapan ideal seperti yang disyaratkan dalam Kurikulum Tingkat Satuan 
Pendidikan (KTSP) dengan standar ideal minimal 75 .

\section{HASIL DAN PEMBAHASAN}

1. Perencanaan Tindakan

Penelitian ini yaitu penerapan media gambar pada mata pelajaran Bahasa Indonesia tema Budi pekerti materi bercerita di kelas 2 SD Kedondong 2 Gajah Demak. Tujuan yang diharapkan yakni adanya peningkatan prestasi belajar siswa. Langkah yang dilakukan pada tahap perencanaan meliputi (a) menyusun instrumen pembelajaran; (b) menyusun instrumen observasi;(c) sosialisasi kepada siswa; ( d) melaksanakan tindakan dalam pembelajaran; e) melakukan refleksi; (f) menyusun strategi pembelajaran pada siklus ke dua berdasar refleksi siklus pertama; (g) melaksanakan pembelajaran pada siklus kedua; (h) melakukan observasi; i) melakukan refleksi pada siklus kedua; j) menyusun strategi pembelajaran pada siklus ketiga berdasar refleksi siklus kedua; (k) melaksanakan pembelajaran pada siklus ketiga; (l) melakukan observasi; (m) melakukan refleksi pada siklus ketiga; dan (n) menyusun laporan.

2. Pelaksanaan Tindakan dan Pengamatan

Pelaksanaan tindakan dalam penelitian dilakukan 3 siklus yang terdiri dari tiga kali pertemuan. Waktu yang digunakan setiap kali pertemuan berlangsung 2 × 35 menit. Pertemuan pertama dilaksanakan pada 09 s.d 17 Januari 2017 dan pertemuan kedua pada 23 s.d 30 Januari 2017, dan pertemuan ketiga 09 s.d 16 Pebruari 2017. Penelitian tindakan kelas dilaksanakan sesuai dengan prosedur rencana pembelajaran dan skenario pembelajaran.

\section{Siklus I}

a.Tahap Perencanaan

Pada tahap ini peneliti mempersiapkan perangkat pembelajaran yang terdiri dari rencana pelajaran 1 , LKS 1 , soal tes formatif 1 dan alat-alat pengajaran yang mendukung. Selain itu juga dipersiapkan lembar observasi pengolaan pembelajaran dengan media gambar. b. Tahap Kegiatan dan Pelaksanaan

Pelaksanaan kegiatan belajar mengajar untuk siklus I dilaksanakan pada 09 s.d 17 Januari 2017 di SDN Kedondong 2 tahun pelajaran 2016 - 2017 dengan jumlah siswa 23 orang. Dalam hal ini peneliti bertindak sebagai guru. Adapun proses belajar mengajar mengacu pada rencana pelajaran yang telah dipersiapkan.

Pengamatan (observasi) dilaksanakan bersamaan dengan pelaksaaan belajar mengajar. Pada akhir proses belajar mengajar siswa diberi tes formatif I dengan tujuan untuk mengetahui tingkat keberhasilan siswa dalam proses belajar mengajar yang telah dilakukan. Adapun data hasil penelitian pada siklus I sebagai berikut.

Tabel 1. Distribusi prestasi belajar siswa pada siklus I

\begin{tabular}{|c|c|c|c|c|}
\hline \multirow[b]{2}{*}{ No } & \multirow[b]{2}{*}{ Nama } & \multirow[b]{2}{*}{ Skor } & \multicolumn{2}{|c|}{ Keterangan } \\
\hline & & & Tuntas & $\begin{array}{c}\text { Tidak } \\
\text { Tuntas }\end{array}$ \\
\hline 1 & ARSZ & 60 & & $\sqrt{ }$ \\
\hline 2 & $\mathrm{AD}$ & 50 & & $\sqrt{ }$ \\
\hline 3 & APA & 70 & & $\sqrt{ }$ \\
\hline 4 & ASA & 70 & & $\sqrt{ }$ \\
\hline 5 & $\mathrm{BS}$ & 50 & & $\sqrt{ }$ \\
\hline 6 & CAK & 70 & $\sqrt{ }$ & \\
\hline 7 & DI & 50 & & $\sqrt{ }$ \\
\hline 8 & FAS & 60 & & $\sqrt{ }$ \\
\hline 9 & FikAS & 70 & $\sqrt{ }$ & \\
\hline 10 & KS & 70 & $\sqrt{ }$ & \\
\hline 11 & KAS & 70 & $\sqrt{ }$ & \\
\hline 12 & MAK & 70 & $\sqrt{ }$ & \\
\hline 13 & MNF & 60 & & $\sqrt{ }$ \\
\hline 14 & MSNA & 50 & & $\sqrt{ }$ \\
\hline 15 & REM & 50 & & $\sqrt{ }$ \\
\hline 16 & RBS & 60 & & $\sqrt{ }$ \\
\hline 17 & SRF & 60 & & $\sqrt{ }$ \\
\hline 18 & TNN & 50 & & $\sqrt{ }$ \\
\hline 19 & FQN & 50 & & $\sqrt{ }$ \\
\hline 20 & APN & 60 & & $\sqrt{ }$ \\
\hline 21 & NAR & 60 & & $\sqrt{ }$ \\
\hline 22 & MRNR & 60 & & $\sqrt{ }$ \\
\hline 23 & MHS & 50 & & $\sqrt{ }$ \\
\hline \multicolumn{2}{|c|}{ Jumlah Total } & 1380 & & \\
\hline \multicolumn{2}{|c|}{$\begin{array}{l}\text { Skor } \\
\text { Maksimum } \\
\text { Individu } \\
\end{array}$} & 100 & - & - \\
\hline \multicolumn{2}{|c|}{$\begin{array}{l}\text { Skor } \\
\text { maksimuim } \\
\text { Kelas } \\
\end{array}$} & 2300 & - & - \\
\hline
\end{tabular}

Berdasarkan tabel di atas dapat dijelaskan bahwa dengan menggunakan media gambar diperoleh nilai rata-rata prestasi belajar siswa adalah 59,57\% atau ada 6 siswa dari 23 siswa sudah tuntas belajar. Hasil tersebut menunjukkan bahwa pada siklus pertama secara klasikal siswa belum tuntas belajar, karena siswa yang memperoleh nilai $\geq 65$ hanya sebesar $27 \%$ lebih kecil dari persentase ketuntasan yang dikehendaki yaitu sebesar 85 $\%$. Hal ini disebabkan siswa masih merasa baru dan belum mengerti apa yang dimaksudkan dan digunakan guru dengan pembelajaran menggunakan media gambar.

c. Tahap Refleksi 
Dalam pelaksanaan kegiatan belajar mengajar diperoleh informasi berdasarkan hasil pengamatan menunjukkan (1) guru kurang baik dalam memotivasi siswa dan dalam menyampaikan tujuan pembelajaran; (2) guru kurang baik dalam pengelolaan waktu; dan (3) siswa kurang begitu antusias selama pembelajaran berlangsung.

d. Revisi Rancangan

Pelaksanaan kegiatan belajar mengajar pada siklus I ini masih terdapat kekurangan, sehingga perlu adanya revisi untuk dilakukan pada siklus berikutnya. Hal hal yang harus diperhatikan (1) guru perlu lebih terampil dalam memotivasi siswa dan lebih jelas dalam menyampaikan tujuan pembelajaran. Di mana siswa diajak untuk terlibat langsung dalam setiap kegiatan yang akan dilakukan; (2) guru perlu mendistribusikan waktu secara baik dengan menambahkan informasi-informasi yang dirasa perlu dan memberi catatan; dan (3) Guru harus lebih terampil dan bersemangat dalam memotivasi siswa sehingga siswa bisa lebih antusias.

\section{Siklus II}

a. Tahap Perencanaan

Pada tahap ini peneliti mempersiapkan perangkat pembelajaran yang terdiri dari rencana pelajaran 2 , soal tes formatif II dan alatalat pengajaran yang mendukung.

b. Tahap kegiatan dan pelaksanaan

Pelaksanaan kegiatan belajar mengajar untuk siklus II dilaksanakan pada 23 s.d 30 Januari 2017 di SDN Kedondong 2 tahun pelajaran 2016-2017. Dalam hal ini peneliti bertindak sebagai guru. Adapun proses belajar mengajar mengacu pada rencana pelajaran dengan memperhatikan revisi pada siklus I, sehingga kesalahan atau kekurangan pada siklus I tidak terulang lagi pada siklus II. Pengamatan (observasi) dilaksanakan bersamaan dengan pelaksanaan belajar mengajar.

Pada akhir proses belajar mengajar siswa diberi tes formatif II dengan tujuan untuk mengetahui tingkat keberhasilan siswa dalam proses belajar mengajar yang telah dilakukan. Instrumen yang digunakan adalah tes formatif II. Adapun data hasil penelitian pada siklus II adalah sebagai berikut.

Tabel 2. Distribusi prestasi belajar siswa pada siklus II

\begin{tabular}{|l|l|c|c|c|}
\hline \multirow{2}{*}{$\begin{array}{l}\text { N } \\
\text { o }\end{array}$} & \multirow{2}{*}{ Nama } & Skor & Keterangan \\
\cline { 4 - 5 } & & & Tuntas & $\begin{array}{c}\text { Tidak } \\
\text { Tuntas }\end{array}$ \\
\hline 1 & ARSZ & 70 & $\sqrt{ }$ & \\
\hline
\end{tabular}

\begin{tabular}{|l|l|l|l|l|}
\hline 2 & AD & 70 & $\sqrt{ }$ & \\
\hline 3 & APA & 70 & $\sqrt{ }$ & \\
\hline 4 & ASA & 70 & $\sqrt{ }$ & \\
\hline 5 & BS & 70 & $\sqrt{ }$ & \\
\hline 6 & CAK & 70 & $\sqrt{ }$ & \\
\hline 7 & DI & 50 & & $\sqrt{ }$ \\
\hline 8 & FAS & 50 & & $\sqrt{ }$ \\
\hline 9 & FikAS & 70 & $\sqrt{ }$ & \\
\hline 10 & KS & 60 & & $\sqrt{ }$ \\
\hline 11 & KAS & 70 & $\sqrt{ }$ & \\
\hline 12 & MAK & 60 & & $\sqrt{ }$ \\
\hline 13 & MNF & 70 & $\sqrt{ }$ & \\
\hline 14 & MSNA & 70 & $\sqrt{ }$ & \\
\hline 15 & REM & 50 & & $\sqrt{ }$ \\
\hline 16 & RBS & 50 & & $\sqrt{ }$ \\
\hline 17 & SRF & 70 & $\sqrt{ }$ & \\
\hline 18 & TNN & 70 & $\sqrt{ }$ & \\
\hline 19 & FQN & 80 & $\sqrt{ }$ & \\
\hline 20 & APN & 50 & & $\sqrt{ }$ \\
\hline 21 & NAR & 50 & & $\sqrt{ }$ \\
\hline 22 & MRNR & 70 & $\sqrt{ }$ & \\
\hline 23 & MHS & 70 & $\sqrt{ }$ & \\
\hline Jumlah Total & $\mathbf{1 3 8 0}$ & $\mathbf{1 . 4 8 0}$ & - \\
\hline $\begin{array}{l}\text { Skor } \\
\text { Maksimum } \\
\text { Individu }\end{array}$ & $\mathbf{1 0 0}$ & $\mathbf{1 0 0}$ & - \\
\hline $\begin{array}{l}\text { Skor } \\
\text { maksimuim } \\
\text { Kelas }\end{array}$ & $\mathbf{2 3 0 0}$ & $\mathbf{2 3 0 0}$ & - \\
\hline & & & \\
\hline
\end{tabular}

Berdasarkan tabel di atas diperoleh nilai rata-rata prestasi belajar siswa adalah $64,35 \%$ dan ketuntasan belajar mencapai $65 \%$ atau ada 15 siswa dari 23 siswa sudah tuntas belajar. Hasil ini menunjukkan bahwa pada siklus II ini ketuntasan belajar secara klasikal telah mengalami peningkatan jauh lebih baik dari siklus I. Adanya peningkatan hasil belajar siswa ini karena setelah guru menginformasikan bahwa setiap akhir pelajaran akan selalu diadakan tes sehingga pada pertemuan berikutnya siswa lebih termotivasi untuk belajar. Selain itu siswa juga sudah mulai mengerti apa yang dimaksudkan dan dinginkan guru dengan menerapkan pembelajaran belajar berdasarkan masalah.

\section{c. Refleksi}

Dalam pelaksanaan kegiatan belajar diperoleh informasi dari hasil pengamatan sebagai berikut: memotivasi siswa, membimbing siswa merumuskan kesimpulan/menemukan konsep dan pengelolaan waktu.

d. Revisi Pelaksanaaan

Pelaksanaan kegiatan belajar pada siklus II ini masih terdapat kekurangan-kekurangan. Oleh karena itu, perlu adanya revisi untuk 
dilaksanakan pada siklus III, yakni (1) guru dalam memotivasi siswa hendaknya dapat membuat siswa lebih termotivasi selama proses belajar mengajar berlangsung; (2) guru harus lebih dekat dengan siswa sehingga tidak ada perasaan takut dalam diri siswa baik untuk mengemukakan pendapat atau bertanya; (3) guru harus lebih sabar dalam membimbing siswa merumuskan kesimpulan/menemukan konsep; (4) guru harus mendistribusikan waktu secara baik sehingga kegiatan pembelajaran dapat berjalan sesuai dengan yang diharapkan; dan (5) guru sebaiknya menambah lebih banyak contoh soal dan memberi soal-soal latihan pada siswa untuk dikerjakan pada setiap kegiatan belajar mengajar.

\section{Siklus III}

a. Tahap Perencanaan

Pada tahap ini peneliti mempersiapkan perangkat pembelajaran yang terdiri dari rencana pelajaran 3, soal tes formatif 3 dan alatalat pengajaran yang mendukung.

b. Tahap kegiatan dan pengamatan

Pelaksanaan kegiatan belajar mengajar untuk siklus III dilaksanakan pada tanggal 09 s.d 16 Pebruari 2017 di SDN Kedondong 2 tahun pelajaran 2016-2017 dengan jumlah siswa 23 siswa. Dalam hal ini peneliti bertindak sebagai guru. Adapun proses belajar mengajar mengacu pada rencana pelajaran dengan memperhatikan revisi pada siklus II, sehingga kesalahan atau kekurangan pada siklus II tidak terulang lagi pada siklus III. Pengamatan (observasi) dilaksanakan bersamaan dengan pelaksanaan belajar mengajar. Pada akhir proses belajar mengajar siswa diberi tes formatif III dengan tujuan untuk mengetahui tingkat keberhasilan siswa dalam proses belajar mengajar yang telah dilakukan. Instrumen yang digunakan adalah tes formatif III. Adapun data hasil penelitian pada siklus III adalah sebagai berikut.

Tabel 3. Distribusi prestasi belajar siswa pada siklus III

\begin{tabular}{|l|l|c|c|c|}
\hline \multirow{2}{*}{$\begin{array}{l}\text { N } \\
\text { o }\end{array}$} & \multirow{2}{*}{ Nama } & \multirow{2}{*}{ Skor } & \multicolumn{2}{|c|}{ Keterangan } \\
\cline { 4 - 5 } & & & Tuntas & $\begin{array}{c}\text { Tidak } \\
\text { Tuntas }\end{array}$ \\
\hline 1 & ARSZ & 80 & $\sqrt{ }$ & \\
\hline 2 & AD & 70 & $\sqrt{ }$ & \\
\hline 3 & APA & 80 & $\sqrt{ }$ & \\
\hline 4 & ASA & 90 & $\sqrt{ }$ & \\
\hline 5 & BS & 80 & $\sqrt{ }$ & \\
\hline 6 & CAK & 80 & $\sqrt{ }$ & \\
\hline 7 & DI & 90 & $\sqrt{ }$ & \\
\hline
\end{tabular}

\begin{tabular}{|l|l|c|c|c|}
\hline 8 & FAS & 70 & $\sqrt{ }$ & \\
\hline 9 & FikAS & 70 & $\sqrt{ }$ & \\
\hline 10 & KS & 80 & $\sqrt{ }$ & \\
\hline 11 & KAS & 80 & $\sqrt{ }$ & \\
\hline 12 & MAK & 80 & $\sqrt{ }$ & \\
\hline 13 & MNF & 90 & $\sqrt{ }$ & \\
\hline 14 & MSNA & 70 & $\sqrt{ }$ & \\
\hline 15 & REM & 60 & & $\sqrt{ }$ \\
\hline 16 & RBS & 60 & & $\sqrt{ }$ \\
\hline 17 & SRF & 80 & $\sqrt{ }$ & \\
\hline 18 & TNN & 70 & $\sqrt{ }$ & \\
\hline 19 & FQN & 80 & $\sqrt{ }$ & \\
\hline 20 & APN & 80 & $\sqrt{ }$ & \\
\hline 21 & NAR & 90 & $\sqrt{ }$ & \\
\hline 22 & MRNR & 80 & $\sqrt{ }$ & \\
\hline 23 & MHS & 80 & $\sqrt{ }$ & \\
\hline Jumlah Total & $\mathbf{1 3 8 0}$ & $\mathbf{1 7 9 0}$ & \\
\hline $\begin{array}{l}\text { Skor } \\
\text { Maksimum } \\
\text { Individu }\end{array}$ & $\mathbf{1 0 0}$ & $\mathbf{1 0 0}$ & - \\
\hline $\begin{array}{l}\text { Skor } \\
\text { maksimum } \\
\text { Kelas }\end{array}$ & $\mathbf{2 3 0 0}$ & $\mathbf{2 3 0 0}$ & - \\
\hline
\end{tabular}

Berdasarkan tabel di atas diperoleh nilai rata-rata tes formatif sebesar $77,83 \%$ dan dari 23 siswa yang telah tuntas sebanyak 21 siswa dan 2 siswa belum mencapai ketuntasan belajar. Maka secara klasikal ketuntasan belajar yang telah tercapai sebesar $91 \%$ (termasuk kategori tuntas). Hasil pada siklus III ini mengalami peningkatan lebih baik dari siklus II. Adanya peningkatan hasil belajar pada siklus III ini dipengaruhi oleh adanya peningkatan kemampuan guru dalam pembelajaran dengan menggunakan media gambar sehingga siswa menjadi lebih terbiasa dengan pembelajaran seperti ini sehingga siswa lebih mudah dalam memahami materi yang telah diberikan. Di samping itu ketuntasan ini juga dipengaruhi oleh kerja sama dari siswa yang telah menguasai materi pelajaran untuk mengajari temannya yang belum menguasai.

c. Refleksi

Pada tahap ini akan dikaji apa yang telah terlaksana dengan baik maupun yang masih kurang baik dalam proses belajar mengajar dengan menggunkan media gambar. Dari datadata yang telah diperoleh dapat duraikan sebagai berikut: (1) selama proses belajar mengajar guru telah melaksanakan semua pembelajaran dengan baik. Meskipun ada beberapa aspek yang belum sempurna, tetapi persentase pelaksanaannya untuk masingmasing aspek cukup besar, (2) berdasarkan data hasil pengamatan diketahui bahwa siswa aktif selama proses belajar berlangsung, (3) 
kekurangan pada siklus-siklus sebelumnya sudah mengalami perbaikan dan peningkatan sehingga menjadi lebih baik, (4) hasil belajar siswa pada siklus III mencapai ketuntasan.

d. Revisi Pelaksanaan

Pada siklus III guru telah menerapkan pembelajaran dan menggunakan media gambar dengan baik dan dilihat dari aktivitas siswa serta hasil belajar siswa pelaksanaan proses belajar mengajar sudah berjalan dengan baik. Maka tidak diperlukan revisi terlalu banyak, tetapi yang perlu diperhatikan untuk tindakan selanjutnya adalah memaksimalkan dan mempertahankan apa yang telah ada dengan tujuan agar pada pelaksanaan proses belajar mengajar selanjutnya dengan menggunakan media gambar dapat meningkatkan proses belajar mengajar sehingga tujuan pembelajaran dapat tercapai.

Bedasarkan hasil tindakan, sejak siklus I sampai siklus III dapat dilihat pada berikut ini.

(1) Terjadi peningkatan prestasi setelah diberi tindakan yaitu terjadi 59,57\% menjadi $64,35 \%$ ada kenaikan sebesar $=4,78 \%$.

(2) Sebelum tindakan (siklus 1) dan setelah tindakan sampai dengan (siklus 3) $59,57 \%$ menjadi $64,35 \%$, dan dari (siklus 2) ke (siklus 3) juga ada peningkatan sebanyak $77,83 \%$ $66,24 \%=13,48 \%$.

(3) Rata - rata siswa sebelum diberi tindakan 59,57 naik 4,78 menjadi 64,35 .

(4) Tindakan siklus 2 dan setelah tindakan (siklus 3) 64,35\% menjadi 77,83\% berarti ada peningkatan prestasi sebanyak $77,83 \%-64,35 \%=$ $13,48 \%$.

1. Refleksi dan Temuan

Berdasarkan pelaksanaan tindakan maka hasil observasi nilai hasil dapat dikatakan sebagai berikut.

Pertemuan pertama kegiatan belajarmengajar melalui pembelajaran dengan menggunakan media gambar belum berhasil karena dalam pembelajaran masih terlihat siswa yang bermain, bercerita, dan mengganggu siswa lain.

(a) Model pembelajaran melalui pembelajaran dengan menggunakan media gambar, dalam hal peningkatan prestasi belum tampak, sehingga hasil yang dicapai tidak tuntas.

(b) Mungkin karena proses belajar mengajar yang dilakukan melalui pembelajaran dengan menggunakan media gambar yang baru mereka laksanakan sehingga siswa merasa kaku dalam menerapkannya.

(c) Mereka setelah dijelaskan dapat mengerti dan buktinya pada pertemuan kedua dan ketiga proses kegiatan belajar - mengajar berjalan baik, semua siswa aktif dan lebih-lebih setelah ada rubrik penilaian proses, seluruh siswa langsung aktif belajar.

Berdasarkan analisis data, diperoleh aktivitas siswa dalam proses pembelajaran materi pembiasaan dengan metode pembelajaran dengan menggunakan media gambar yang paling dominan adalah bekerja dengan menggunakan alat/media, mendengarkan/memperhatikan penjelasan guru, dan diskusi antar siswa/antara siswa dengan guru. Jadi dapat dikatakan bahwa aktivitas siswa dapat dikategorikan aktif.

Mengenai aktivitas guru selama pembelajaran telah melaksanakan langkahlangkah metode pembelajaran dengan menggunakan media gambar dengan baik. Hal ini terlihat dari aktivitas guru yang muncul di tengah aktivitas membimbing dan mengamati siswa dalam mengerjakan kegiatan pembelajaran, menjelaskan, memberi umpan balik/evaluasi/tanya jawab sehingga persentase untuk aktivitas di atas cukup besar.

Berdasarkan hasil penelitian tersebut, maka hasil belajar siswa pada pelajaran bahasa indonesia dengan menggunakan media gambar pada setiap pertemuan mengalami kenaikan setiap siklusnya. Hal itu tampak pada pertemuan pertama dari 25 orang siswa yang hadir pada saat penelitian ini dilakukan nilai rata rata mencapai ; 59,57 \% meningkat menjadi 64,35 $\%$ dan pada siklus 3 meningkat menjadi 77,83 $\%$.

Berdasarkan analisis data di atas menunjukkan bahwa pembelajaran dengan menggunakan belajar berasarkan masalah yang diterapkan pada pembelajaran bahasa indonesia , yang berarti proses kegiatan belajar mengajar lebih berhasil dan dapat meningkatkan prestasi belajar siswa khususnya pada siswa kelas II , oleh karena itu diharapkan kepada para guru SD dapat melaksanakan pembelajaran dengan menggunakan media gambar.

Berdasarkan kerikulum tingkat satuan pendidikan (KTSP) siswa dikatakan tuntas apabila siswa telah mencapai nilai standar ideal 75 mencapai $\geq 85 \%$. Sedangkan pada penilitian ini, pencapai nilai $\geq 75$ pada ( siklus 3 ) mencapai melebihi target yang ditetapkan dalam KTSP yaitu mencapai 91,00 \%. Dengan 
demikian maka hipotesis yang diajukan dapat diterima.

\section{SIMPULAN}

Berdasarkan analisis hasil peneletian dan diskusi dapat disimpulkan sebagai berikut.

1. Keterampilan dalam pengelolaan pembelajaran dengan menggunakan media gambar menunjukkan peningkatan pada tiap tiap putaran.

2. Aktivitas siswa dalam kegiatan belajar mengajar menunjukkan bahwa seluruh siswa dapat melaksanakan pembelajaran dengan baik dalam setiap aspek.

3. Dengan menerapkan model pembelajaran dengan menggunakan media gambar menunjukkan peningkatan pada tiap siklus.

4. Prestasi belajar siswa pada tiap siklus secara kuantitatif mulai siklus I, II, dan III mengalami kenaikan masing masing sebesar $59,57 \% ; 64,35 \% ; 77,83 \%$.Secara keseluruhan dapat disimpulkan bahwa untuk melakukan suatu model pembelajaran perlu persiapan guru yang benar benar dapat menunjang tujuan yang akan dicapai dan disertai dengan pemahaman guru terhadap model yang dibawakan, materi yang disampaikan dan penilaian yang dilakukan harus menjadi siklus satu kesatuan utuh.

5. Efektivitas pembelajaran siswa menunjukkan bahwa kegiatan belajar mengajar dengan menerapkan pembelajaran dengan menggunakan media gambar bermanfaat dan membantu siswa untuk lebih mudah memahami materi bercerita serta siswa merasa senang dengan diterapkannya model pembelajaran tersebut.

\section{DAFTAR PUSTAKA}

Ali Rahman, Nur. 1996. Strategi Belajar Mengajar. Surabaya: CV. Citra.

Arikunto, S dkk. 2007. Penelitian Tindakan Kelas. Jakarta : PT Bumi Aksara.
Arikunto, S. 2006. Prosedur Penelitian: Suatu Pendekatan Praktik. Jakarta: Rineka Cipta.

Depdikbud. 2003. Pendekatan Kontekstual. Jakarta : Depdikbud.

Gunawan, Munir. 1999. Penelitian Tindakan. Jakarta : Depdikbud

Hopkins, D. 1993 A Teacher's Guide to Classroom Research, Buckingham: Open University.

Mas Aboe Dhari. 1993. Metodologi Pembelajaran. Jakarta. Depdikbud

Sadiman, Arief. dkk. 2007. Media Pendidikan, Pengertian, Pengembangan, dan Pemanfaatannya. Jakarta: PT Raja Grafindo Persada.

Sardiman, AM. 1996. Interaksi dan Motivasi Belajar Mengajar. Jakarta : PT Grafindo Persada.

Shell, D. F., Colvin, C., dan Bruning, R. H. 1995. Self-Efficacy, Attributions, and Outcome Expectancy Mechanisms in Reading and Writing Achievement:Grade-level and Achievement-level Differences. Journal of Educational Psychology, 87. [Online]. Tersedia: http://www.des.emory. edu/mfp/effchapter.html

Silberman, Melvin L. 2006. Active Learning 101 Cara Belajar Siswa Aktif. Bandung: Nuansa.

Tim Pelatih Proyek UGM. 1999. Bahan Pelatihan Dosen LPTK dan Guru Sekolah Menengah. Jakarta : PGSM Dirjen Dikti. 